\title{
Analisis Kinerja Keuangan Bank Aceh Setelah Konversi Periode 2016-2018 Berdasarkan Peraturan Otoritas Jasa Keuangan Nomor 8/POJK.03/2014
}

\author{
Hanifa Assofia \\ Pascasarjana UIN Sumatera Utara Medan \\ nifasofia@yahoo.com
}

\begin{abstract}
This research aims to find out how Bank Aceh's financial performance after conversion in terms of earnings and capital. The type of research used is quantitative descriptive research. The data collection method used is the documentation method based on the data in the form of quarterly financial statements for the 2016-2018 period published. The method of data analysis in this study is by using the RGEC method (Risk Profile, Good Corporate Governance, Earning and Capital). The results of the study show that Bank Aceh's financial performance in terms of profitability ranks 2 , with the definition that profitability is adequate, profit exceeds the target and supports the growth of bank capital. Bank Aceh's decision to convert to sharia as a whole was a very appropriate decision because it was able to show good performance, besides that it also supported the Aceh Government in carrying out its programs to enforce Islamic law. Bank Aceh's financial performance in terms of capital also ranks 2, with the definition that banks have adequate capital quality and adequacy relative to their risk profile, which is accompanied by strong capital management in accordance with the characteristics, scale of business and the complexity of the bank's business.
\end{abstract}

Keywords: Financial Performance, Earning, Capital, Bank Aceh, OJK Regulation

\begin{abstract}
Abstrak
Penelitian ini bertujuan untuk mengetahui bagaimana kinerja keuangan Bank Aceh setelah konversi dari sisi rentabilitas dan sisi permodalan. Jenis penelitian ini adalah penelitian deskriptif kuantitatif. Metode pengumpulan data yang digunakan yaitu metode dokumentasi berdasarkan data-data berupa laporan keuangan triwulanan periode 2016-2018 yang telah dipublikasikan. Metode analisis data dalam penelitian ini yaitu dengan menggunakan metode RGEC (Risk Profile, Good Corporate Governance, Earning, and Capital). Hasil penelitian menunjukkan bahwa kinerja keuangan Bank Aceh dari sisi rentabilitas mendapat peringkat 2, dengan definisi bahwa rentabilitas memadai, laba melebihi target dan mendukung pertumbuhan permodalan bank. Keputusan Bank Aceh untuk melakukan konversi menjadi syariah secara menyeluruh merupakan keputusan yang sangat tepat karena mampu menunjukkan kinerja yang baik, selain itu juga mendukung Pemerintah Aceh dalam menjalankan programnya untuk menegakkan syariat Islam. Kinerja keuangan Bank Aceh dari sisi permodalan (capital) juga mendapat peringkat 2, dengan definisi bahwa bank memiliki kualitas dan kecukupan permodalan yang memadai relatif terhadap profil risikonya, yang disertai dengan pengelolaan permodalan yang kuat sesuai dengan karakteristik, skala usaha, dan kompleksitas usaha bank.
\end{abstract}

Kata Kunci: Kinerja Keuangan, Rentabilitas, Permodalan, Bank Aceh, Peraturan OJK 


\section{Pendahuluan}

Meningkatnya inovasi dalam produk, jasa, dan aktivitas perbankan syariah berpengaruh pada peningkatan kompleksitas usaha dan profil risiko bank yang apabila tidak diimbangi dengan penerapan manajemen risiko yang memadai dapat menimbulkan berbagai permasalahan mendasar pada bank maupun terhadap sistem keuangan secara keseluruhan. Agar bank mampu mengidentifikasi permasalahan lebih dini, melakukan tindak lanjut perbaikan yang sesuai dan lebih cepat, serta menerapkan prinsip Good Corporate Governance dan manajemen risiko yang lebih baik maka Otoritas Jasa Keuangan menyempurnakan sistem penilaian tingkat kesehatan bank.

Pada prinsipnya tingkat kesehatan, pengelolaan bank, dan kelangsungan usaha bank merupakan tanggung jawab sepenuhnya dari manajemen bank. Oleh karena itu, bank wajib memelihara, memperbaiki, dan meningkatkan tingkat kesehatannya dengan menerapkan prinsip kehati-hatian dan manajemen risiko dalam melaksanakan kegiatan usahanya termasuk melakukan penilaian sendiri (self assessment) secara berkala terhadap tingkat kesehatannya dan mengambil langkah-langkah perbaikan secara efektif. Di lain pihak, Otoritas Jasa Keuangan mengevaluasi, menilai tingkat kesehatan bank, dan melakukan tindakan pengawasan yang diperlukan dalam rangka menjaga stabilitas sistem perbankan dan keuangan. ${ }^{1}$

Untuk mengukur kinerja keuangan Bank Syariah dapat dilakukan dengan mengacu pada standar penilaian yang telah ditetapkan oleh Otoritas Jasa Keuangan melalui Peraturan Otoritas Jasa Keuangan Nomor 8/POJK.03/2014 tentang Penilaian Tingkat Kesehatan Bank Umum Syariah dan Unit Usaha Syariah. Bank Umum Syariah wajib melakukan penilaian Tingkat Kesehatan Bank baik secara individual maupun secara konsolidasi, dengan cakupan penilaian terhadap faktor-faktor sebagai berikut: a) Profil Risiko (risk profile); b) Good Corporate Governance (GCG); c) Rentabilitas (earnings); dan d) Permodalan (capital). ${ }^{2}$ Namun, dalam penelitian ini penulis hanya akan melakukan analisis kinerja keuangan Bank Aceh setelah konversi dari faktor rentabilitas dan faktor permodalan saja, sehingga faktor profil risiko dan faktor GCG tidak termasuk ke dalam faktor yang akan dianalisis.

Penilaian terhadap faktor rentabilitas meliputi penilaian terhadap kinerja rentabilitas, sumber-sumber rentabilitas, dan stabilitas rentabilitas (sustainability 
learnings) Bank Umum Syariah. Penilaian terhadap faktor permodalan meliputi penilaian terhadap tingkat kecukupan permodalan dan pengelolaan permodalan Bank Umum Syariah. ${ }^{3}$

Bank Aceh merupakan salah satu BPD di Indonesia yang melakukan konversi atau perubahan sistem operasional perbankan dari sistem konvensional menjadi sistem syariah secara menyeluruh. Setelah melakukan konversi, Bank Aceh banyak sekali mendapatkan penghargaan atau apresiasi nasional atas kinerja keuangannya tahun 2017, yaitu meraih lima penghargaan sekaligus pada acara penghargaan Bank Umum Syariah Nasional "Karim Award 2018" yang diselenggarakan di Gedung Taman Ismail Marzuki, Jakarta Pusat. Corporate Secretary Bank Aceh, Amal Hasan, lewat siaran pers kepada Serambi, mengatakan bahwa konversi yang dilakukan Bank Aceh merupakan keputusan yang tepat untuk meningkatkan ekonomi daerah berbasis kerakyatan berkonsep ekonomi Islam. Beliau juga berharap agar bank lain dapat mengikuti jejak Bank Aceh dalam rangka memajukan sistem perekonomian syariah di Indonesia. Ia menambahkan dengan konversi itu, Bank Aceh terus menunjukkan trend positif tidak hanya dari segi kinerja keuangan, tetapi juga dari sisi eksistensinya yang tentu turut didukung oleh nasabah setia dan masyarakat Aceh. ${ }^{4}$

Beberapa peneliti sebelumnya telah melakukan penelitian di Bank Aceh seperti penelitian yang dilakukan oleh Farlian dan Nuraidar, di mana penelitian tersebut bertujuan untuk mengetahui bagaimana reaksi pasar atas konversi yang dilakukan oleh Bank Aceh. Penelitian ini berhubungan dengan para pengusaha, pemerintah, lembaga-lembaga/institusi, BUMN, swasta, kemitraan, dan para pemegang saham lainnya yang menjadikan Bank Aceh sebagai bank utama mereka. Hasil penelitian menunjukkan beragam pendapat dan sangat sedikit masyarakat yang menolak perubahan sistem operasional yang dilakukan oleh Bank Aceh, kebanyakan dari masyarakat memberikan respon yang positif terhadap konversi tersebut. ${ }^{5}$

Selanjutnya penelitian yang dilakukan oleh Nisa, di mana penelitian tersebut bertujuan untuk mengetahui apakah terdapat perbedaan kinerja Bank Aceh Syariah sebelum dan sesudah konversi. Rasio keuangan yang digunakan adalah ROA, ROE, FDR, dan BOPO. Peneliti menggunakan data laporan keuangan bulanan Bank Aceh Syariah, yaitu laporan bulanan Juni 2015 sampai dengan Agustus 2016 untuk data sebelum konversi dan laporan bulanan Oktober 2016 
sampai dengan Desember 2017 untuk data setelah konversi. Hasil penelitian menunjukkan bahwa pada rasio ROA dan BOPO tidak terdapat perbedaan antara sebelum dan sesudah konversi. Sedangkan pada rasio ROE dan FDR terdapat perbedaan antara sebelum dan sesudah konversi. ${ }^{6}$

Berdasarkan uraian di atas, penulis tertarik untuk melakukan penelitian lebih lanjut mengingat Bank Aceh telah banyak mendapatkan apresiasi nasional atas kinerja keuangannya setelah konversi sehingga diketahui apakah Bank Aceh mampu mempertahankan kinerja keuangannya yang sudah dinilai baik sebelumnya untuk periode berikutnya dengan mengikuti ketentuan yang telah ditetapkan dalam Peraturan Otoritas Jasa Keuangan Nomor 8/POJK.03/2014 tentang Penilaian Tingkat Kesehatan Bank Umum Syariah dan Unit Usaha Syariah.

\section{Kinerja Keuangan}

Kinerja keuangan adalah gambaran hasil ekonomi yang mampu diraih oleh perusahaan atau perbankan pada periode tertentu melalui aktivitas-aktivitas perusahaan untuk menghasilkan keuntungan secara efisien dan efektif yang dapat diukur perkembangannya dengan cara menganalisis data-data keuangan yang tercantum dalam laporan keuangan. Kinerja dalam kamus istilah akuntansi adalah kuantifikasi dari keefektifan dalam operasi bisnis yang terjadi selama periode tertentu. Kinerja bank secara umum merupakan gambaran prestasi yang dicapai oleh bank dalam kegiatan operasionalnya. Kinerja keuangan bank adalah gambaran kondisi keuangan bank pada suatu periode tertentu baik mencakup aspek penghimpunan dana maupun penyaluran dananya. Kinerja dapat menunjukkan kekuatan serta kelemahan dari suatu perusahaan. ${ }^{7}$

Analisis kinerja keuangan bank bertujuan untuk mengetahui keberhasilan pengelolaan keuangan bank terutama kondisi likuiditas, kecukupan modal dan profitabilitas yang dicapai dalam tahun berjalan maupun tahun sebelumnya serta untuk mengetahui kemampuan bank dalam mendayagunakan semua aset yang dimiliki dalam menghasilkan profit secara efisien. ${ }^{8}$

Prosedur yang dilakukan dalam analisis keuangan, yaitu: 1) Mengumpulkan data keuangan dan data pendukung yang diperlukan selengkap mungkin, baik untuk satu periode maupun beberapa periode; 2) Melakukan pengukuran- 
pengukuran atau perhitungan-perhitungan dengan rumus-rumus tertentu, sesuai dengan standar yang biasa digunakan secara cermat dan teliti, sehingga hasil yang diperoleh benar-benar tepat; 3) Melakukan perhitungan dengan memasukkan angka-angka yang ada dalam laporan keuangan secara cermat; 4) Memberikan interpretasi terhadap hasil perhitungan dan pengukuran yang telah dibuat; 5) Membuat laporan tentang posisi keuangan perusahaan; 6) Memberikan rekomendasi yang dibutuhkan sehubungan dengan hasil analisis tersebut. ${ }^{9}$

Dalam praktiknya, terdapat dua macam metode analisis laporan keuangan yang biasa dipakai, yaitu analisis vertikal (statis) dan analisis horizontal (dinamis). Kemudian teknik analisis keuangan terdiri dari analisis perbandingan antara laporan keuangan, analisis trend, analisis persentase per komponen, analisis sumber dan penggunaan dana, analisis sumber dan penggunaan kas, analisis rasio, analisis kredit, analisis laba kotor, serta analisis titik impas (break even point). ${ }^{10}$

\section{Penelitian Terdahulu}

Berikut ini beberapa penelitian terdahulu terkait dengan analisis kinerja keuangan bank, antara lain:

Andri Veno dan Syamsudin melakukan penelitian tentang analisis trend kinerja keuangan perbankan syariah tahun 2015-2017. Hasil penelitian menunjukkan bahwa kinerja perbankan syariah tahun 2008-2014 cenderung meningkat dari segi profitabilitas rasio keuangan REO dengan angka tertinggi di tahun 2009. Trend peramalan kinerja perbankan syariah tahun 2015-2017 juga terus mengalami pertumbuhan dari segi profitabilitas rasio keuangan REO dengan prediksi paling tinggi di tahun 2016. ${ }^{11}$

Theresia Vania Hamolin dan Nila Firdaus Nuzula melakukan penelitian tentang analisis tingkat kesehatan bank berdasarkan Metode Risk Based Bank Rating (Studi Pada Bank Umum Konvensional di Indonesia Periode 2014-2016). Hasil penelitian menunjukkan bahwa kondisi profil risiko NPL dari Bank Umum Konvensional di Indonesia tahun 2014-2016 mayoritas dalam kondisi baik; kondisi penilaian self assessment GCG Bank Umum Konvensional di Indonesia tahun 2014-2016 mayoritas dalam kondisi baik; kondisi rentabilitas berdasarkan ROA dari Bank Umum Konvensional di Indonesia tahun 2014-2016 mayoritas dalam kondisi sangat baik; kondisi permodalan berdasarkan rasio CAR dari Bank Umum Konvensional di Indonesia tahun 2014-2016 mayoritas dalam kondisi 
sangat baik. Berdasarkan tingkat kesehatan bank umum konvensional di Indonesia tahun 2014-2016 dinilai dengan Metode Risk Based Bank Rating, peneliti merekomendasikan BCA dan BRI karena selalu mendapatkan predikat "Sangat Baik". 12

\section{Kerangka Berfikir}

Dalam penelitian ini, terlebih dahulu penulis akan melakukan review data laporan keuangan triwulanan Bank Aceh periode 2016-2018. Selanjutnya melakukan perhitungan rasio-rasio keuangan dari setiap parameter/indikator faktor rentabilitas dan faktor permodalan. Kemudian mengukur rasio-rasio tersebut dengan berdasarkan standar penilaian yang telah ditetapkan dalam Peraturan Otoritas Jasa Keuangan Nomor 8/POJK.03/2014 tentang Penilaian Tingkat Kesehatan Bank Umum Syariah dan Unit Usaha Syariah agar diketahui pakah kinerja keuangan Bank tersebut sangat baik, baik, cukup baik, kurang baik atau bahkan buruk berdasarkan faktor rentabilitas dan faktor permodalan. Setelah dilakukan pengukuran, selanjutnya menginterpretasikan hasil perhitungan dan pengukuran yang telah dibuat. Hasil interpretasi mencerminkan keberhasilan maupun permasalahan apa yang dicapai perusahaan dalam pengelolaan keuangan.

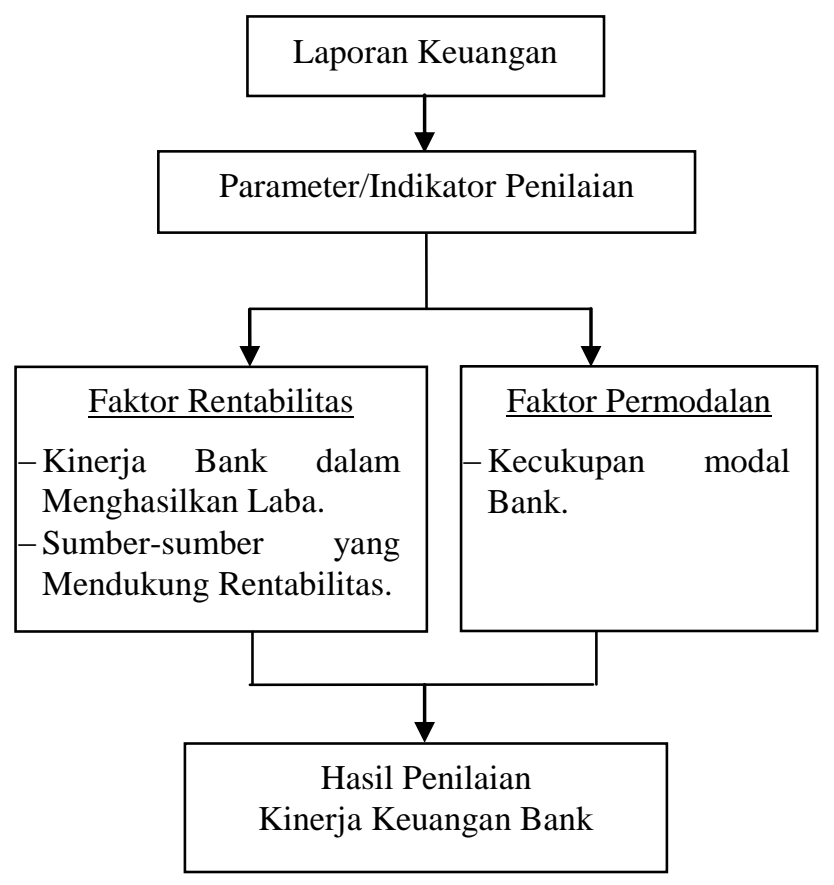

Gambar 1 Kerangka Berfikir 
Hanifa Assofia: Analisis Kinerja Keuangan Bank Aceh Setelah Konversi |49

\section{Metode Penelitian}

Penelitian ini merupakan jenis penelitian deskriptif kuantitatif. Penelitian deskriptif dalam penelitian ini dimaksudkan untuk menganalisis kinerja keuangan Bank Aceh setelah konversi periode 2016-2018 berdasarkan Peraturan Otoritas Jasa Keuangan Nomor 8/POJK.03/2014 tentang Penilaian Tingkat Kesehatan Bank Umum Syariah dan Unit Usaha Syariah.

Jenis data dalam penelitian ini adalah data kuantitatif. Sedangkan sumber data yang digunakan adalah data sekunder berupa laporan keuangan triwulanan Bank Aceh periode 2016-2018. Metode pengumpulan data yang digunakan dalam penelitian ini adalah metode dokumentasi, yaitu dengan cara membaca, mengamati, mencatat, serta mempelajari uraian buku-buku, jurnal-jurnal akuntansi dan bisnis, serta mengunduh data dan informasi dari situs resmi Bank Aceh, yaitu http://www.bankaceh.co.id/.

Penelitian ini dilakukan untuk mengetahui nilai variabel mandiri, tanpa membuat perbandingan atau menghubungkan dengan variabel yang lain. Variabel dalam penelitian ini adalah kinerja keuangan, yang diukur dengan rasio rentabilitas dan rasio permodalan. Rasio rentabilitas merupakan alat untuk menganalisis atau mengukur tingkat efisiensi usaha dan kemampuan bank dalam menghasilkan laba. Rasio permodalan adalah rasio yang digunakan untuk mengukur kemampuan bank dalam menyerap kerugian-kerugian yang tidak dapat dihindari lagi serta dapat pula digunakan untuk mengukur besar kecilnya kekayaan bank tersebut atau kekayaan yang dimiliki oleh para pemegang sahamnya.

Metode analisis data dalam penelitian ini yaitu dengan menggunakan metode RGEC (risk profile, good corporate governance, earning, and capital) sebagaimana yang telah diatur ketentuan-ketentuannya dalam Surat Edaran Otoritas Jasa Keuangan Nomor 10/SEOJK.03/2014 tentang Penilaian Tingkat Kesehatan Bank Umum Syariah dan Unit Usaha Syariah.

Matriks parameter/indikator penilaian dari masing-masing faktor pengukuran kinerja keuangan adalah sebagai berikut:

1. Matriks Parameter/Indikator Penilaian Faktor Rentabilitas

a. Kinerja Bank dalam Menghasilkan Laba (Rentabilitas)

1) Return on Asset (ROA) 


$$
\frac{\text { Laba Sebelum Pajak }}{\text { Rata - rata Total Aset }}
$$

Keterangan:

- Laba sebelum pajak adalah laba sebagaimana tercatat dalam laba rugi Bank tahun berjalan sebagaimana diatur dalam ketentuan yang berlaku mengenai Laporan Stabilitas Moneter dan Sistem Keuangan Bulanan Bank Umum Syariah dan Unit Usaha Syariah, yang disetahunkan.

- Rata-rata total aset adalah rata-rata total aset dalam Laporan Posisi Keuangan sebagaimana tertera pada Laporan Stabilitas Moneter dan Sistem Keuangan Bulanan Bank Umum Syariah dan Unit Usaha Syariah.

2) Net Operation Margin (NOM)

$$
\frac{\text { Pendapatan Penyaluran Dana Stlh Bagi Hasil - Beban Operasional }}{\text { Rata - rata Aktiva Produktif }}
$$

Keterangan:

- Pendapatan penyaluran dana setelah bagi hasil adalah pendapatan penyaluran dana setelah dikurangi beban bagi hasil dan beban operasional (disetahunkan). Pendapatan penyaluran dana meliputi seluruh pendapatan dari penyaluran dana, sedangkan beban bagi hasil meliputi seluruh beban bagi hasil dari penghimpunan dana.

- Beban operasional adalah beban operasional termasuk beban bagi hasil dan bonus (disetahunkan).

- Aktiva produktif yang diperhitungkan adalah aset yang menghasilkan bagi hasil, imbalan, dan bonus baik di neraca maupun pada TRA.

3) Net Imbalan (NI)

$\underline{\text { Pendapatan Penyaluran Dana Stlh Bagi Hasil - (Imbalan dan Bonus) }}$

$$
\text { Rata - rata Total Aktiva Produktif }
$$

Keterangan:

- Pendapatan penyaluran dana setelah bagi hasil - (imbalan dan bonus) adalah pendapatan penyaluran dana setelah dikurangi beban imbal hasil, imbalan, dan bonus (disetahunkan). Pendapatan penyaluran dana meliputi seluruh pendapatan dari penyaluran dana, sedangkan beban imbal hasil meliputi seluruh beban bagi hasil, imbalan, dan bonus dari penghimpunan dana. 
Hanifa Assofia: Analisis Kinerja Keuangan Bank Aceh Setelah Konversi |51

- Aktiva produktif yang diperhitungkan adalah aset yang menghasilkan bagi hasil, imbalan, dan bonus baik di neraca maupun pada TRA.

b. Sumber-sumber yang Mendukung Rentabilitas

1) Pendapatan Penyaluran Dana Setelah Bagi Hasil dikurangi Imbalan dan Bonus terhadap Rata-rata Total Aset

Pendapatan Penyaluran Dana Stlh Bagi Hasil - (Imbalan dan Bonus)

Rata - rata Total Aset

Keterangan:

- Pendapatan penyaluran dana setelah bagi hasil, imbalan dan bonus adalah pendapatan penyaluran dana setelah dikurangi beban imbal hasil, imbalan, dan bonus (disetahunkan).

- Pendapatan penyaluran dana meliputi seluruh pendapatan dari penyaluran dana, sedangkan beban imbal hasil meliputi seluruh beban bagi hasil, imbalan, dan bonus dari penghimpunan dana.

- Rata-rata total aset adalah rata-rata total aset dalam Laporan Posisi Keuangan sebagaimana tertera pada Laporan Stabilitas Moneter dan Sistem Keuangan Bulanan Bank Umum Syariah dan Unit Usaha Syariah.

2) Pendapatan Operasional Lainnya terhadap Rata-rata Total Aset

$$
\frac{\text { Pendapatan Operasional Lainnya }}{\text { Rata - rata Total Aset }}
$$

Keterangan:

- Pendapatan operasional lainnya adalah pendapatan operasional lainnya disetahunkan.

- Rata-rata total aset adalah rata-rata total aset dalam Laporan Posisi Keuangan sebagaimana tertera pada Laporan Stabilitas Moneter dan Sistem Keuangan Bulanan Bank Umum Syariah dan Unit Usaha Syariah.

3) Beban Overhead terhadap Rata-rata Total Aset

$$
\frac{\text { Beban Overhead }}{\text { Rata - rata Total Aset }}
$$

Keterangan:

- Beban overhead adalah seluruh biaya-biaya operasional yang bukan merupakan beban bagi hasil (disetahunkan) meliputi biaya: a) 
52 |AT-TAWASSUTH: Volume IV No. 1 Januari - Juni 2019: 43 - 65

penyusutan/amortisasi aset; b) biaya tenaga kerja; c) pendidikan dan pelatihan; d) premi asuransi; e) kerugian karena risiko operasional; f) penelitian dan pengembangan; g) sewa; h) promosi; i) pajak-pajak (tidak termasuk pajak penghasilan); j) pemeliharaan dan perbaikan; k) barang dan jasa; danl) lainnya.

- Rata-rata Total Aset adalah rata-rata total aset dalam Laporan Posisi Keuangan sebagaimana tertera pada Laporan Stabilitas Moneter dan Sistem Keuangan Bulanan Bank Umum Syariah dan Unit Usaha Syariah.

4) Beban Pencadangan terhadap Rata-rata Total Aset

$$
\frac{\text { Beban Pencadangan }}{\text { Rata - rata Total Aset }}
$$

Keterangan:

- Beban pencadangan adalah seluruh biaya-biaya yang dikeluarkan untuk pencadangan berupa kerugian penurunan nilai aset keuangan \& ppa non produktif (disetahunkan).

- Rata-rata total aset adalah rata-rata total aset dalam Laporan Posisi Keuangan sebagaimana tertera pada Laporan Stabilitas Moneter dan Sistem Keuangan Bulanan Bank Umum Syariah dan Unit Usaha Syariah.

5) Beban Operasional terhadap Pendapatan Operasional (BOPO)

$$
\frac{\text { Beban Operasional }}{\text { Pendapatan Operasional }}
$$

Keterangan:

- Beban operasional adalah beban operasional termasuk beban bagi hasil dan bonus (disetahunkan).

- Pendapatan operasional adalah pendapatan penyaluran dana.

Matriks peringkat faktor rentabilitas:

a) Peringkat 1, Rentabilitas sangat memadai, laba melebihi target dan mendukung pertumbuhan permodalan Bank.

b) Peringkat 2, Rentabilitas memadai, laba melebihi target dan mendukung pertumbuhan permodalan Bank. 
Hanifa Assofia: Analisis Kinerja Keuangan Bank Aceh Setelah Konversi |53

c) Peringkat 3, Rentabilitas cukup memadai, laba memenuhi target, namun terdapat tekanan terhadap kinerja laba yang dapat menyebabkan penurunan laba namun cukup dapat mendukung pertumbuhan permodalan Bank.

d) Peringkat 4, Rentabilitas kurang memadai, laba tidak memenuhi target, dan diperkirakan akan tetap seperti kondisi tersebut di masa datang sehingga kurang dapat mendukung pertumbuhan permodalan Bank dan kelangsungan usaha Bank.

e) Peringkat 5, Rentabilitas tidak memadai, laba tidak memenuhi target dan tidak dapat diandalkan serta memerlukan peningkatan kinerja laba segera untuk memastikan kelangsungan usaha Bank.

2. Matriks Parameter/Indikator Penilaian Faktor Permodalan

a) Rasio Kecukupan Modal Bank

1) Kewajiban Penyediaan Modal Minimum (KPMM)

$$
\frac{\text { Modal }}{\text { ATMR }}
$$

Keterangan:

- Perhitungan modal dan aset tertimbang menurut risiko (ATMR) berpedoman pada ketentuan yang berlaku mengenai kewajiban penyediaan modal minimum bank umum berdasarkan prinsip syariah.

- Rasio dihitung per posisi penilaian termasuk memperhatikan trend KPMM.

2) Modal Inti terhadap ATMR

$$
\frac{\text { Modal Inti (Tier } 1)}{\text { ATMR }}
$$

Keterangan:

Perhitungan modal inti berpedoman pada ketentuan yang berlaku mengenai Kewajiban Penyediaan Modal Minimum Bank Umum Berdasarkan prinsip syariah.

3) Modal Inti terhadap Total Modal

$$
\frac{\text { Modal Inti }}{\text { Total Modal }}
$$

Keterangan: 
54 | AT-TAWASSUTH: Volume IV No. 1 Januari - Juni 2019: 43 - 65

- Perhitungan modal inti berpedoman pada ketentuan yang berlaku mengenai KPMM bank umum berdasarkan prinsip syariah.

- Total modal adalah modal sesuai dengan ketentuan yang berlaku mengenai kewajiban penyediaan modal minimum bank umum berdasarkan prinsip syariah.

4) Critized Assets (Kualitas Rendah) dikurangi CKPN (Kualitas Rendah) terhadap Modal Inti dan Cadangan Umum

$$
\frac{\text { Critized Assets (Kualitas Rendah) - CKPN }}{\text { Modal Inti + Cadangan Umum }}
$$

Keterangan:

- Critized Assets adalah aset produktif neraca dengan kualitas rendah yaitu aset produktif yang memiliki kualitas dalam perhatian khusus, kurang lancar, diragukan, dan macet sesuai ketentuan yang berlaku mengenai Kualitas Aktiva/Aset, termasuk pembiayaan direstrukturisasi kualitas lancar, AYDA kualitas lancar, properti terbengkalai kualitas lancar, dan penyertaan modal sementara kualitas lancar.

- CKPN kualitas rendah adalah cadangan kerugian penurunan nilai untuk pembiayaan yang tergolong dalam perhatian khusus, kurang lancar, diragukan, dan macet, termasuk CKPN untuk pembiayaan direstrukturisasi kualitas lancar, AYDA kualitas lancar, properti terbengkalai kualitas lancar, dan penyertaan modal sementara kualitas lancar.

5) Aset Produktif Bermasalah dikurangi CKPN Aset Produktif Bermasalah terhadap Modal Inti dan Cadangan Umum

$$
\frac{\text { Aset Produktif Bermasalah - CKPN }}{\text { Modal Inti + Cadangan Umum }}
$$

Keterangan:

- Aset produktif adalah sebagaimana dimaksud dalam ketentuan yang berlaku mengenai penilaian kualitas aktiva/aset bagi bank umum syariah dan unit usaha syariah

- Aset produktif bermasalah adalah aset produktif dengan kualitas kurang lancar, diragukan, dan macet. 
Hanifa Assofia: Analisis Kinerja Keuangan Bank Aceh Setelah Konversi |55

- CKPN aset produktif bermasalah adalah CKPN yang dibentuk atas aset produktif dengan kualitas kurang lancar, diragukan, dan macet.

6) Aset Kualitas Rendah dikurangi CKPN untuk Aset Kualitas Rendah terhadap Modal Inti dan Cadangan Umum

$$
\frac{\text { Aset Kualitas Rendah }- \text { CKPN }}{\text { Modal Inti + Cadangan Umum }}
$$

Keterangan:

- Aset kualitas rendah adalah seluruh aktiva bank baik produktif maupun non produktif yang memiliki kualitas dalam perhatian khusus, kurang lancar, diragukan, dan macet sesuai ketentuan yang berlaku mengenai kualitas aktiva/aset, termasuk pembiayaan direstrukturisasi kualitas lancar, AYDA kualitas lancar, properti terbengkalai kualitas lancar, dan penyertaan modal sementara kualitas lancar.

- CKPN untuk aset kualitas rendah adalah CKPN yang dibentuk atas aset dengan kualitas dalam perhatian khusus, kurang lancar, diragukan, dan macet, termasuk CKPN untuk pembiayaan direstrukturisasi kualitas lancar, AYDA kualitas lancar, properti terbengkalai kualitas lancar, dan penyertaan modal sementara kualitas lancar.

\section{Matriks peringkat faktor permodalan:}

1. Peringkat 1, bank memiliki kualitas dan kecukupan permodalan yang sangat memadai relatif terhadap profil risikonya, yang disertai dengan pengelolaan permodalan yang sangat kuat sesuai dengan karakteristik, skala usaha, dan kompleksitas usaha bank.

2. Peringkat 2, bank memiliki kualitas dan kecukupan permodalan yang memadai relatif terhadap profil risikonya, yang disertai dengan pengelolaan permodalan yang kuat sesuai dengan karakteristik, skala usaha, dan kompleksitas usaha bank.

3. Peringkat 3, bank memiliki kualitas dan kecukupan permodalan yang cukup memadai relatif terhadap profil risikonya, yang disertai dengan pengelolaan permodalan yang cukup kuat sesuai dengan karakteristik, skala usaha, dan kompleksitas usaha bank. 
4. Peringkat 4, bank memiliki kualitas dan kecukupan permodalan yang kurang memadai relatif terhadap profil risikonya, yang disertai dengan pengelolaan permodalan yang lemah dibandingkan dengan karakteristik, skala usaha, dan kompleksitas usaha bank.

5. Peringkat 5, bank memiliki kualitas dan kecukupan permodalan yang tidak memadai relatif terhadap profil risikonya, yang disertai dengan pengelolaan permodalan yang sangat lemah dibandingkan dengan karakteristik, skala usaha, dan kompleksitas usaha bank.

\section{Hasil Penelitian dan Pembahasan}

\section{Kinerja Keuangan Bank Aceh dari Sisi Rentabilitas}

Penilaian kinerja keuangan Bank Aceh dari sisi rentabilitas selama periode 2016-2018 berdasarkan laporan keuangan triwulanan dalam penelitian ini dibatasi ke dalam dua parameter, yaitu: a) kinerja bank dalam menghasilkan laba, yang terdiri dari return on asset (ROA), Net Operation Margin (NOM), dan Net Imbalan (NI); b) sumber-sumber yang mendukung rentabilitas, yang terdiri dari pendapatan penyaluran dana setelah bagi hasil dikurangi beban operasional terhadap rata-rata total aset, pendapatan operasional lainnya terhadap rata-rata total aset, beban overhead terhadap rata-rata total aset, beban pencadangan terhadap rata-rata total aset, dan beban operasional terhadap pendapatan operasional (BOPO).

Untuk lebih jelasnya, penulis merangkum hasil penelitian pada tabel 1 dan tabel 2 sebagai berikut:

Tabel 1 Kinerja Bank dalam Menghasilkan Laba

\begin{tabular}{|c|c|c|c|c|}
\hline \multicolumn{2}{|c|}{ Tahun } & $\begin{array}{c}\text { ROA } \\
\text { (R1) }\end{array}$ & $\begin{array}{c}\text { NOM } \\
\text { (R2) }\end{array}$ & $\begin{array}{c}\text { NI } \\
\text { (R3) }\end{array}$ \\
\hline 2016 & IV & $0,51 \%$ & $(1,98 \%)$ & $1,90 \%$ \\
\hline \multirow{4}{*}{2017} & $\mathbf{T}$ & $3,40 \%$ & $2,91 \%$ & $7,70 \%$ \\
\hline & II & $2,75 \%$ & $1,82 \%$ & $7,31 \%$ \\
\hline & III & $2,53 \%$ & $1,68 \%$ & $7,50 \%$ \\
\hline & IV & $2,51 \%$ & $1,56 \%$ & $7,61 \%$ \\
\hline \multirow{2}{*}{2018} & I & $2,50 \%$ & $2,04 \%$ & $7,53 \%$ \\
\hline & II & $2,40 \%$ & $1,89 \%$ & $7,43 \%$ \\
\hline \multicolumn{2}{|c|}{ Rata-rata } & $2,37 \%$ & $1,42 \%$ & $6,71 \%$ \\
\hline
\end{tabular}


Data pada Tabel 1 di atas menunjukkan bagaimana kinerja Bank Aceh dalam menghasilkan laba (rentabilitas) selama periode 2016-2018 berdasarkan nilai ROA, NOM, dan NI.

\section{Return On Asset (ROA)}

Secara keseluruhan, ROA yang dihasilkan Bank Aceh selama periode tersebut sudah sangat baik, karena nilai rata-rata yang diperoleh adalah sebesar 2,36\% atau >1,5\%. ROA Bank Aceh tertinggi terdapat pada triwulan I tahun 2017 yaitu sebesar 3,40\%, di mana pada periode ini ROA masuk dalam kategori sangat baik karena nilai yang dihasilkan lebih dari 1,5\%. Sedangkan ROA Bank Aceh terendah terjadi pada triwulan IV tahun 2016 yaitu sebesar $0,51 \%$, di mana pada periode ini ROA dikategorikan cukup baik karena rasio yang dihasilkan berada di antara $0,5 \%$ sampai dengan $1,25 \%$.

Jika dilihat dari perkembangannya seperti yang ditunjukkan pada Tabel $1 \mathrm{di}$ atas, maka dapat diketahui bahwa ROA Bank Aceh cenderung mengalami penurunan pada setiap triwulannya, hanya mengalami peningkatan pada triwulan I tahun 2017. Walaupun ROA terus mengalami penurunan pada triwulan-triwulan berikutnya, hal ini tidak menjadikan Bank Aceh berada dalam kondisi yang buruk jika diukur berdasarkan nilai ROA.

ROA merupakan rasio yang digunakan untuk mengukur keberhasilan manajemen dalam menghasilkan laba. Semakin kecil rasio ini mengindikasikan kurangnya kemampuan manajemen Bank dalam hal mengelola aktiva untuk meningkatkan pendapatan dan atau menekan biaya. Berdasarkan teori tersebut, hal ini mengindikasikan bahwa walaupun secara umum ROA Bank Aceh sudah berada dalam kondisi yang sangat baik, akan tetapi terjadi penurunan kinerja pada setiap periodenya sehingga perlu diketahui apa saja yang menjadi penyebab penurunan rasio tersebut agar pihak manajemen bank dapat mengetahui langkahlangkah perbaikan yang perlu dilakukan ke depan yang berkaitan dengan kemampuan bank dalam mendayagunakan semua aset yang dimiliki dalam menghasilkan laba secara efisien.

\section{Net Operation Margin (NOM)}

NOM merupakan rasio yang digunakan untuk mengukur pendapatan bersih dari operasi utama terhadap total penyaluran dana. NOM yang dihasilkan Bank Aceh selama periode 2016-2018 cenderung mengalami penurunan, bahkan pada 
triwulan IV tahun 2016 rasio NOM yang diperoleh menunjukkan hasil yang negatif. NOM Bank Aceh tertinggi terjadi pada triwulan I tahun 2017 yaitu sebesar 2,91\%, di mana pada periode ini NOM dapat dikategorikan baik karena rasio yang dihasilkan berada di antara $2 \%$ sampai dengan $3 \%$. Sedangkan NOM Bank Aceh terendah terjadi pada triwulan IV tahun 2016 yaitu sebesar -1,98\%, di mana pada periode ini NOM masuk dalam kategori buruk karena nilai yang dihasilkan $\leq 1 \%$ dan bahkan menunjukkan hasil yang negatif.

Jika dilihat dari perkembangannya seperti yang ditunjukkan pada Tabel 1 di atas, maka dapat diketahui bahwa NOM Bank Aceh cenderung mengalami penurunan dan tidak menunjukkan hasil perhitungan yang terlalu tinggi atau dalam kondisi ini dapat dikategorikan cukup baik karena hampir secara keseluruhan NOM yang dihasilkan Bank Aceh berada di bawah 2\%. NOM Bank Aceh hanya mengalami peningkatan pada triwulan I tahun 2017 dan triwulan I tahun 2018.

NOM Bank Aceh yang cenderung mengalami penurunan mengindikasikan bahwa kemampuan manajemen Bank Aceh dalam menghasilkan laba juga mengalami penurunan. Dampak dari penurunan kinerja NOM akan membuat nasabah, pemilik saham, dan pihak lainnya merasa kurang puas terhadap efisiensi Bank Aceh dalam menghasilkan laba karena pendapatan untuk masing-masing pihak tersebut akan berkurang. Sebaliknya, jika terjadi peningkatan kinerja NOM akan memperkuat kepercayaan nasabah, pemilik saham, dan pihak lainnya karena akan memberikan pendapatan yang lebih besar.

\section{Net Imbalan (NI)}

NI merupakan rasio yang digunakan untuk mengukur kemampuan bank dalam menghasilkan laba dengan cara membandingkan pendapatan penyaluran dana setelah bagi hasil dikurangi imbalan dan bonus dengan rata-rata aktiva produktif. NI Bank Aceh selama periode 2016-2018 menunjukkan hasil perhitngan yang baik dengan nilai rata-rata yang diperoleh yaitu sebesar 6,71\%. NI Bank Aceh tertinggi terjadi pada triwulan I tahun 2017 yaitu sebesar 7,70\%, sedangkan NI Bank Aceh terendah terjadi pada triwulan IV tahun 2016 yaitu sebesar $1,90 \%$.

Penjelasan dari tabel 1 terkait dengan kinerja Bank Aceh dalam menghasilkan laba (rentabilitas) selama periode 2016-2018 berdasarkan laporan 
keuangan triwulanan yang diukur berdasarkan nilai ROA, NOM, dan NI menunjukkan bahwa kemampuan Bank Aceh dalam menghasilkan laba secara keseluruhan dapat dikatakan baik karena laba yang dihasilkan telah memenuhi target dan bahkan dalam beberapa periode tertentu laba melebihi target atau ketentuan yang telah ditetapkan pemerintah terkait dengan rasio-rasio tersebut.

Selanjutnya sumber-sumber yang mendukung rentabilitas Bank Aceh yang terdiri dari pendapatan penyaluran dana bersih dikurangi imbalan dan bonus terhadap rata-rata total aset, pendapatan operasional lainnya terhadap rata-rata total aset, beban overhead terhadap rata-rata total aset, beban pencadangan terhadap rata-rata total aset, dan BOPO akan dirangkum dalam tabel 2 sebagai berikut:

Tabel 2 Sumber-Sumber Yang Mendukung Rentabilitas

\begin{tabular}{|c|c|c|c|c|c|c|}
\hline \multicolumn{2}{|c|}{ Tahun } & \multirow{2}{*}{$\begin{array}{c}\text { Pendapatan } \\
\text { Penyaluran } \\
\text { Dana Bersih - } \\
\text { Imbalan dan } \\
\text { Bonus } \\
\text { terhadap RTA } \\
1,78 \%\end{array}$} & \multirow{2}{*}{$\begin{array}{c}\text { Pendapatan } \\
\text { Operasional } \\
\text { Lainnya } \\
\text { terhadap } \\
\text { RTA }\end{array}$} & \multirow{2}{*}{$\begin{array}{c}\text { Beban } \\
\begin{array}{c}\text { Overhead } \\
\text { terhadap } \\
\text { RTA }\end{array} \\
4,00 \%\end{array}$} & \multirow{2}{*}{$\begin{array}{c}\text { Beban } \\
\text { Pencadangan } \\
\text { terhadap } \\
\text { RTA } \\
1,79 \%\end{array}$} & \multirow{2}{*}{\begin{tabular}{|l} 
BOPO \\
$94,43 \%$
\end{tabular}} \\
\hline 2016 & IV & & & & & \\
\hline \multirow{4}{*}{2017} & $\mathbf{I}$ & $7,11 \%$ & $0,56 \%$ & $4,62 \%$ & $0,84 \%$ & $69,69 \%$ \\
\hline & II & $6,80 \%$ & $0,88 \%$ & $5,31 \%$ & $0,56 \%$ & $75,43 \%$ \\
\hline & III & $6,99 \%$ & $0,82 \%$ & $5,56 \%$ & $0,46 \%$ & $77,23 \%$ \\
\hline & IV & $7,10 \%$ & $0,86 \%$ & $5,65 \%$ & $0,37 \%$ & $78,00 \%$ \\
\hline \multirow{2}{*}{2018} & I & $7,01 \%$ & $0,51 \%$ & $5,12 \%$ & $0,21 \%$ & $76,76 \%$ \\
\hline & II & $6,90 \%$ & $0,60 \%$ & $5,15 \%$ & $0,33 \%$ & $76,81 \%$ \\
\hline \multicolumn{2}{|c|}{ Rata-rata } & $6,24 \%$ & $0,91 \%$ & $5,06 \%$ & $0,65 \%$ & $78,34 \%$ \\
\hline
\end{tabular}

Data pada tabel 2 menunjukkan kinerja Bank Aceh dalam menghasilkan laba jika diukur berdasarkan rasio-rasio penunjangnya, yang terdiri dari pendapatan penyaluran dana bersih dikurangi imbalan dan bonus terhadap ratarata total aset, pendapatan operasional lainnya terhadap rata-rata total aset, beban overhead terhadap rata-rata total aset, beban pencadangan terhadap rata-rata total aset, dan BOPO.

Pendapatan penyaluran dana bersih dikurangi imbalan dan bonus terhadap rata-rata total aset tertinggi yang dihasilkan bank selama periode 2016-2018 yaitu terdapat pada triwulan I tahun 2017 sebesar 7,11\%. Sedangkan rasio terendah terdapat pada triwulan IV tahun 2016 sebesar 1,78\%. Rasio rata-rata yang diperoleh selama periode tersebut adalah sebesar $6,24 \%$. 
Pendapatan operasional lainnya terhadap rata-rata total aset tertinggi yang dihasilkan bank selama periode 2016-2018 yaitu terdapat pada triwulan IV tahun 2016 sebesar 2,12\%. Sedangkan rasio terendah yang dihasilkan bank terdapat pada triwulan I tahun 2018 yaitu sebesar 0,51\%. Rasio rata-rata yang diperoleh selama periode tersebut adalah sebesar $0,91 \%$.

Beban overhead terhadap rata-rata total aset tertinggi yang dihasilkan bank selama periode 2016-2018 yaitu terdapat pada triwulan IV tahun 2017 sebesar $5,65 \%$. Sedangkan rasio terendah yang dihasilkan bank sebesar 4,00\%. Rasio ratarata yang diperoleh selama periode tersebut adalah sebesar 5,06\%.

Beban pencadangan terhadap rata-rata total aset tertinggi yang dihasilkan bank selama periode 2016-2018 yaitu terdapat pada triwulan IV tahun 2016 sebesar $1,79 \%$. Sedangkan rasio terendah yang dihasilkan bank sebesar 0,21\%. Rasio rata-rata yang diperoleh selama periode tersebut adalah sebesar $0,65 \%$.

BOPO tertinggi yang dihasilkan bank selama periode 2016-2018 yaitu pada triwulan IV tahun 2016 sebesar 94,43\% sehingga pada periode tersebut bank dikategorikan tidak baik dalam hal efisiensi karena rasio BOPO $>89 \%$. Sedangkan rasio BOPO terendah yang mampu dihasilkan bank yaitu pada triwulan I tahun 2017 sebesar 69,69\% sehingga pada periode tersebut bank dapat dikategorikan sangat baik.

Berdasarkan penjelasan dari tabel 1 dan tabel 2 terkait dengan kinerja Bank Aceh dalam menghasilkan laba (rentabilitas) dan sumber-sumber yang mendukung rentabilitas selama periode 2016-2018 berdasarkan laporan keuangan triwulanan yang dipublikasikan, dapat diambil kesimpulan bahwa kinerja Bank Aceh dari sisi rentabilitas mendapat peringkat 2, dengan definisi bahwa rentabilitas memadai, laba melebihi target dan mendukung pertumbuhan permodalan Bank. Keputusan Bank Aceh untuk melakukan konversi menjadi syariah secara menyeluruh merupakan keputusan yang sangat tepat karena mampu menunjukkan kinerja yang baik, selain itu juga mendukung Pemerintah Aceh dalam menjalankan programnya untuk menegakkan syariat Islam.

\section{Kinerja Keuangan Bank Aceh dari Sisi Permodalan}

Dalam penelitian ini, penilaian kinerja keuangan Bank Aceh dari sisi permodalan selama periode 2016-2018 diukur berdasarkan rasio kecukupan modal yang terdiri dari kewajiban penyediaan modal minimum (KPMM), modal inti 
terhadap ATMR, modal inti terhadap total modal, critized assets (kualitas rendah) dikurangi CKPN (kualitas rendah) terhadap modal inti dan cadangan umum, aset produktif bermasalah dikurangi CKPN aset produktif bermasalah terhadap modal inti dan cadangan umum, serta aset kualitas rendah dikurangi CKPN untuk aset kualitas rendah terhadap modal inti dan cadangan umum.

Tabel 3 Rasio Kecukupan Modal

\begin{tabular}{|c|c|c|c|c|c|c|c|}
\hline \multicolumn{2}{|c|}{ Tahun } & KРMM & $\begin{array}{c}\text { Modal } \\
\text { Inti Trhdp } \\
\text { ATMR }\end{array}$ & $\begin{array}{l}\text { Modal } \\
\text { Inti } \\
\text { Trhdp } \\
\text { Total } \\
\text { Modal }\end{array}$ & $\begin{array}{c}\text { Critized } \\
\text { Assets } \\
\text { (Kualitas } \\
\text { Rendah) - } \\
\text { CKPN Thdp } \\
\text { Modal Inti + } \\
\text { Cad. Umum }\end{array}$ & $\begin{array}{c}\text { AP Brmslh } \\
\text { - CKPN } \\
\text { Thdp Modal } \\
\text { Inti + Cad. } \\
\text { Umum }\end{array}$ & $\begin{array}{c}\text { Aset } \\
\text { Kualitas } \\
\text { Rendah - } \\
\text { CKPN } \\
\text { Thdp } \\
\text { Modal Inti } \\
\text { + Cad. } \\
\text { Umum }\end{array}$ \\
\hline 2016 & IV & $20,74 \%$ & $19,28 \%$ & $92,97 \%$ & $12,41 \%$ & $0,72 \%$ & $12,41 \%$ \\
\hline \multirow{4}{*}{2017} & I & $22,59 \%$ & $21,14 \%$ & $93,58 \%$ & $18,40 \%$ & $1,40 \%$ & $18,40 \%$ \\
\hline & II & $19,39 \%$ & $16,48 \%$ & $84,96 \%$ & $37,73 \%$ & $1,48 \%$ & $37,73 \%$ \\
\hline & III & $21,13 \%$ & $18,24 \%$ & $86,35 \%$ & $27,22 \%$ & $0,34 \%$ & $27,22 \%$ \\
\hline & IV & $21,50 \%$ & $19,80 \%$ & $92,12 \%$ & $12,18 \%$ & $0,47 \%$ & $12,18 \%$ \\
\hline \multirow{2}{*}{2018} & I & $21,71 \%$ & $19,96 \%$ & $91,95 \%$ & $20,60 \%$ & $1,05 \%$ & $20,60 \%$ \\
\hline & II & $21,34 \%$ & $19,61 \%$ & $91,90 \%$ & $19,11 \%$ & $1,27 \%$ & $19,11 \%$ \\
\hline
\end{tabular}

Data pada tabel 3 di atas menunjukkan bagaimana kinerja keuangan Bank Aceh dari sisi permodalan selama periode 2016-2018 diukur berdasarkan rasio kecukupan modal yang terdiri dari KPMM, modal inti terhadap ATMR, modal inti terhadap total modal, critized assets (kualitas rendah) dikurangi CKPN (kualitas rendah) terhadap modal inti dan cadangan umum, aset produktif bermasalah dikurangi CKPN aset produktif bermasalah terhadap modal inti dan cadangan umum, serta aset kualitas rendah dikurangi CKPN untuk aset kualitas rendah terhadap modal inti dan cadangan umum.

Secara keseluruhan KPMM yang dihasilkan bank selama periode 2016-2018 pada setiap triwulannya selalu berada dalam kondisi yang sangat baik dikarenakan KPMM $\geq 12 \%$. KPMM Bank Aceh tertinggi terjadi pada triwulan I tahun 2017 yaitu mencapai 22,6\%, sedangkan KPMM Bank Aceh terendah terjadi pada triwulan II tahun 2017 yaitu sebesar 19,4\%.

Modal inti terhadap ATMR tertinggi yang dihasilkan bank selama periode 2016-2018 yaitu terdapat pada triwulan I tahun 2017 sebesar 21,1\%. Rasio terendah yang dihasilkan bank terdapat pada triwulan II tahun 2017 sebesar $16,5 \%$. Rata-rata rasio yang diperoleh bank selama periode tersebut adalah 19,2\%. 
Modal inti terhadap total modal tertinggi yang dihasilkan bank selama periode 2016-2018 yaitu terdapat pada triwulan I tahun 2017 sebesar 93,6\%. Rasio terendah yang dihasilkan bank terdapat pada triwulan II tahun 2017 sebesar $85,0 \%$. Rata-rata rasio yang diperoleh bank selama periode tersebut adalah $90,6 \%$.

Critized assets (kualitas rendah) dikurangi CKPN (kualitas rendah) terhadap modal inti dan cadangan umum tertinggi yang dihasilkan bank selama periode 2016-2018 yaitu terdapat pada triwulan II tahun 2017 sebesar 37,7\%. Rasio terendah yang dihasilkan bank terdapat pada triwulan IV tahun 2017 sebesar $12,2 \%$. Rata-rata rasio yang diperoleh bank selama periode tersebut adalah $21,1 \%$.

Aset produktif bermasalah dikurangi CKPN aset produktif bermasalah terhadap modal inti dan cadangan umum tertinggi yang dihasilkan bank selama periode 2016-2018 yaitu terdapat pada triwulan II tahun 2017 sebesar 1,48\%. Rasio terendah yang dihasilkan bank terdapat pada triwulan III tahun 2017 sebesar $0,34 \%$. Rata-rata rasio yang diperoleh bank selama periode tersebut adalah $0,96 \%$.

Aset kualitas rendah dikurangi CKPN untuk aset kualitas rendah terhadap modal inti dan cadangan umum tertinggi yang dihasilkan bank selama periode 2016-2018 yaitu terdapat pada triwulan II tahun 2017 sebesar 37,7\%. Rasio terendah yang dihasilkan bank terdapat pada triwulan IV tahun 2017 sebesar $12,2 \%$. Rata-rata rasio yang diperoleh bank selama periode tersebut adalah $21,1 \%$.

Berdasarkan penjelasan dari tabel 3 terkait dengan rasio kecukupan modal Bank Aceh selama periode 2016-2018 berdasarkan laporan keuangan triwulanan, dapat diambil kesimpulan bahwa Bank Aceh mendapat peringkat 2, dengan definisi bahwa bank memiliki kualitas dan kecukupan permodalan yang memadai relatif terhadap profil risikonya, yang disertai dengan pengelolaan permodalan yang kuat sesuai dengan karakteristik, skala usaha, dan kompleksitas usaha bank.

\section{Kesimpulan}

Sebagaimana yang telah dipaparkan pada hasil penelitian dan pembahasan sebelumnya, maka dapat dibuat kesimpulan sebagai berikut:

a. Kinerja keuangan Bank Aceh setelah konversi selama periode 2016-2018 dari sisi rentabilitas (earning) mendapat peringkat 2, dengan definisi bahwa 
rentabilitas memadai, laba melebihi target dan mendukung pertumbuhan permodalan bank.

b. Kinerja keuangan Bank Aceh setelah konversi selama periode 2016-2018 dari sisi permodalan (capital) mendapat peringkat 2, dengan definisi bahwa bank memiliki kualitas dan kecukupan permodalan yang memadai relatif terhadap profil risikonya, yang disertai dengan pengelolaan permodalan yang kuat sesuai dengan karakteristik, skala usaha, dan kompleksitas usaha bank.

Berdasarkan kesimpulan di atas, maka saran-saran yang dapat diberikan adalah bagi Bank Aceh, hendaknya pihak manajemen bank harus lebih efektif dan efisien lagi dalam mendayagunakan seluruh aset yang dimiliki agar dapat meningkatkan pendapatan serta menekan biaya-biaya yang ada sehingga diharapkan nantinya perolehan laba bank dapat ditingkatkan. Sedangkan bagi peneliti selanjutnya, penelitian ini hanya mengukur kinerja keuangan Bank Aceh dari sisi rentabilitas dan sisi permodalan saja, diharapkan agar peneliti lainnya juga melakukan penilaian terhadap faktor profil risiko dan faktor Good Corporate Governance (GCG).

\section{Catatan}

${ }^{1}$ Otoritas Jasa Keuangan, Surat Edaran Otoritas Jasa Keuangan No. 10/SEOJK.03/2014 Tentang Penilaian Tingkat Kesehatan Bank Umum Syariah dan Unit Usaha Syariah, (Jakarta: Otoritas Jasa Keuangan, 2014), h. 1-2

2 Otoritas Jasa Keuangan, Peraturan Otoritas Jasa Keuangan Nomor 8/POJK.03/2014 Tentang Penilaian Tingkat Kesehatan Bank Umum Syariah dan Unit Usaha Syariah, (Jakarta: Otoritas Jasa Keuangan, 2014).

${ }^{3}$ Ibid., h. 6

4 http://aceh.tribunnews.com/2018/04/20/bank-aceh-raih-lima-penghargaan Diakses: Tanggal 02/08/2018, Pukul 20:05 WIB.

5 Talbani Farlian dan Nuraidar, "Meretas Reaksi Jalan Panjang Bank Aceh Konversi Syariah”, JURNAL PERSPEKTIF EKONOMI DARUSSALAM, Vol. 3, No. 1, 2017, h. 39

${ }^{6}$ Uswatun Nisa, "Analisis Perbandingan Kinerja PT. Bank Aceh Syariah Sebelum dan Sesudah Konversi", Electronic theses and dissertations (ETD) Universitas Syiah Kuala, 2018. Diakses melalui http://etd.unsyiah.ac.id/index.php?p=show_detail\&id=41813 pada Tanggal 27/09/2018, Pukul 22:47 WIB.

${ }^{7}$ Eskasari Putri dan Arief Budhi Dharma, ”Analisis Perbedaan Kinerja Keuangan Antara Bank Konvensional Dengan Bank Syariah", Riset Akuntansi dan Keuangan Indonesia, Vol. 1, No. 2, 2016, h. 102

${ }^{8}$ Jumingan, Analisis Laporan Keuangan....., h. 239

${ }^{9}$ Kasmir, Analisis Laporan Keuangan....., h. 69

${ }^{10}$ Ibid., h. 69-72

11 Andri Veno dan Syamsudin, "Analisis Trend Kinerja Keuangan Perbankan Syariah Tahun 2015-2017”, Jurnal Bisnis dan Manejemen Islam, Vol. 4, No.1, 2016.

${ }^{12}$ Theresia Vania Hamolin dan Nila Firdaus Nuzula, "Analisis Tingkat Kesehatan Bank Berdasarkan Metode Risk Based Bank Rating (Studi Pada Bank Umum Konvensional di Indonesia Periode 2014-2016)", Jurnal Administrasi Bisnis (JAB), Vol. 57, No. 1, 2018. 


\section{Daftar Pustaka}

Bank Aceh. 2016. Laporan Publikasi Triwulan IV Tahun 2016. Banda Aceh: PT. Bank Aceh Syariah.

Bank Aceh. 2017. Laporan Publikasi Triwulan I Tahun 2017. Banda Aceh: PT. Bank Aceh Syariah.

Bank Aceh. 2017. Laporan Publikasi Triwulan II Tahun 2017. Banda Aceh: PT. Bank Aceh Syariah.

Bank Aceh. 2017. Laporan Publikasi Triwulan III Tahun 2017. Banda Aceh: PT. Bank Aceh Syariah.

Bank Aceh. 2017. Laporan Publikasi Triwulan IV Tahun 2017. Banda Aceh: PT. Bank Aceh Syariah.

Bank Aceh. 2018. Laporan Publikasi Triwulan I Tahun 2018. Banda Aceh: PT. Bank Aceh Syariah.

Bank Aceh. 2018. Laporan Publikasi Triwulan II Tahun 2018. Banda Aceh: PT. Bank Aceh Syariah.

Bank Indonesia. 2008. Undang-Undang Republik Indonesia Nomor 21 Tahun 2008 Tentang Perbankan Syariah. Jakarta: Bank Indonesia.

Farlian, Talbani dan Nuraidar, "Meretas Reaksi Jalan Panjang Bank Aceh Konversi Syariah", JURNAL PERSPEKTIF EKONOMI DARUSSALAM, Vol. 3, No. 1, 2017.

Hamolin, Theresia Vania dan Nila Firdaus Nuzula, "Analisis Tingkat Kesehatan Bank Berdasarkan Metode Risk Based Bank Rating (Studi Pada Bank Umum Konvensional di Indonesia Periode 2014-2016)", Jurnal Administrasi Bisnis (JAB), Vol. 57, No. 1, 2018.

Jumingan. 2014. Analisis Laporan Keuangan. Jakarta: Bumi Aksara.

Kasmir. 2012. Analisis Laporan Keuangan. Jakarta: Rajawali Pers.

Nisa, Uswatun "Analisis Perbandingan Kinerja PT. Bank Aceh Syariah Sebelum dan Sesudah Konversi", Electronic theses and dissertations (ETD) Universitas Syiah Kuala, 2018. Diakses melalui http://etd.unsyiah.ac.id/index.php?p=show_detail\&id=41813

Otoritas Jasa Keuangan. 2014. Peraturan Otoritas Jasa Keuangan Nomor 8/POJK.03/2014 Tentang Penilaian Tingkat Kesehatan Bank Umum Syariah dan Unit Usaha Syariah. Jakarta: Otoritas Jasa Keuangan. 
Hanifa Assofia: Analisis Kinerja Keuangan Bank Aceh Setelah Konversi |65

Otoritas Jasa Keuangan. 2014. Surat Edaran Otoritas Jasa Keuangan Nomor 10/POJK.03/2014 Tentang Penilaian Tingkat Kesehatan Bank Umum Syariah dan Unit Usaha Syariah. Jakarta: Otoritas Jasa Keuangan.

Otoritas Jasa Keuangan. 2014. Lampiran III Surat Edaran Otoritas Jasa Keuangan Nomor 8/POJK.03/2014 Tentang Penilaian Tingkat Kesehatan Bank Umum Syariah dan Unit Usaha Syariah. Jakarta: Otoritas Jasa Keuangan.

Putri, Eskasari dan Arief Budhi Dharma, "Analisis Perbedaan Kinerja Keuangan Antara Bank Konvensional Dengan Bank Syariah”, Riset Akuntansi dan Keuangan Indonesia, Vol. 1, No. 2, 2016.

Veno, Andri dan Syamsudin, "Analisis Trend Kinerja Keuangan Perbankan Syariah Tahun 2015-2017”, Jurnal Bisnis dan Manejemen Islam, Vol. 4, No. 1, 2016. 